\title{
CONFLICTS THE HARMONY OF MULTIETHNIC VILLAGE IN OVERCOMING
}

\author{
Yuyun Yunita \\ Institut Agama Islam An Nur Lampung, Indonesia \\ Email: yuyunyutia@annurac.id
}

\author{
M. Nasor \\ Universitas Islam Negeri (UIN) Raden Intan Lampung, Indonesia \\ Email: Nasor@uinradenintan.ac.id \\ MA. Achlami Hs \\ Universitas Islam Negeri (UIN) Raden Intan Lampung, Indonesia \\ Email: achlami@uinradenintan.ac.id \\ Fitri Yanti \\ Universitas Islam Negeri (UIN) Raden Intan Lampung, Indonesia \\ Email: fitriyanti@uinradenintan.ac.id
}

\begin{abstract}
In everyday life, the basic identity of an ethnic group is often manipulated. Basic identity can possibly be deactivated, activated and also narrowed down because the basic identity is not something that is rigid like a stone but more like liquid, so it can flow and develop in order to make adjustment in life. But sometimes, the flow of basic identity can possibly crash strongly like a flood breaking the dams, and destroy everything that goes through. In certain circumstances, the basic identity which manifests its existence in the form of primodial bonds gives space to powerful emotional cohesion or excessive ethnocentrism, thus becoming a source of calamity.Based on the problems as above, multi-cultural government needs to offer an alternative based on diversity utilization in society. The importance of conducting this research is based on the objective conditions of preliminary research data, when this problem is ignored in this time, it can become a problem in the future, and conflicts can be avoided due to the application of multiethnic based areas.
\end{abstract}

Keywords: Conflicts, Harmony, Multiethnic.

Abstrak

Dalam kehidupan sehari-hari, identitas dasar suatu kelompok etnis sering dimanipulasi. Identitas dasar mungkin dapat dinonaktifkan, diaktifkan, dan juga dipersempit karena identitas dasar bukanlah sesuatu yang kaku seperti batu tetapi lebih seperti cairan, sehingga dapat mengalir dan berkembang untuk membuat penyesuaian dalam kehidupan. Tetapi kadang-kadang, aliran identitas dasar mungkin sangat kuat seperti banjir yang menghancurkan bendungan, dan menghancurkan semua yang terjadi. Dalam keadaan tertentu, identitas dasar yang memanifestasikan keberadaannya dalam bentuk ikatan primodial memberi ruang bagi kohesi emosional yang kuat atau etnosentrisme yang berlebihan, sehingga menjadi sumber bencana. Berdasarkan masalah-masalah di atas, pemerintah multi-budaya perlu menawarkan alternatif berdasarkan pemanfaatan keanekaragaman di masyarakat. Pentingnya melakukan penelitian ini didasarkan pada kondisi obyektif dari data penelitian pendahuluan, ketika masalah ini diabaikan saat ini, itu bisa menjadi masalah di masa depan, dan konflik dapat dihindari karena penerapan area berbasis multietnis.

Kata kunci: Konflik, Harmoni, Multietnis. 


\section{A. Introduction}

Indonesia is one of the biggest multiethnic countries in the world. It is reflected in the diversity in its sociocultural and geographical aspect. Specifically, Indonesia consists of approximately 17,000 large and small islands included in its territory with 228 million people as its population, consisting of 300 tribes using almost 200 different languages.

There are approximately 931 ethnic groups with 731 languages existed in Indonesia. They are divided into major and minor ethnic groups. The major ethnic groups in Indonesia are Java, Sundanese, Madurese, Malay, Balinese, Minangkabau, Batak, Dayak, Bugis and Chinese. As a multiethnic country, not only the physical form but also the religious, legal, architectural, medicinal, food and artistic systems of Indonesian people vary according to their ethnicity. Indonesia is also a country with a strong religious tradition. There are five major religions in Indonesia, namely Islam, Catholicism, Protestantism, Hinduism, and Buddhism. In recent years, after 1998, Kong $\mathrm{Hu} \mathrm{Cu}^{\prime}$ 's religion has also begun to revive in Indonesia.

With such differences, it becomes the basic identity of each ethnic in Indonesia. That basic identity is obtained descriptively and not easy to deny, it arises in social interactions among ethnic groups. In the interaction, people from different ethnic groups will realize that there are group differences between them. The basic identity then becomes a distinction between the various ethnic groups when they interact to each other. Basic identity is the source of their primordial bond, a bond that was born out of family relationships or blood relationship (lineage), race, religious belief or the environment, as well as specific language or dialect. An equation of blood relations, dialects, races, habits will lead to emotional bonds ${ }^{1}$ thatare sometimesexcessive that they can become really destructive ${ }^{2}$. These bonds can be considered a "legacy" of a social nature that has existed ... a "continual sustainability" and which most of them are linked by the family ties, but more than that it is a legacy that comes from birth in the midst of a religious community, which speaks in a particular language dialect, and following certain social practices.

In everyday life, the basic identity of an ethnic group is often manipulated. Basic identity can possibly be deactivated, activatedand also narrowed down because the basic identity is not something that is rigid like a stone but more like liquid, so it can flow and develop in order to make adjustment in life. But sometimes, the flow of basic identity can possibly crash strongly like a flood breaking the dams, and destroy everything that goes through. In certain circumstances, the basic identity which manifests its existence in the form of primodial bonds gives space to powerful emotional cohesion or excessive ethnocentrism, thus becoming a source of calamity.

On the other hand, emotional cohesion derived from primordial ties can lead to a sense of security, warmth or trust among themselves. A sense of trust among the people for a particular ethnic group can be the basis for business activities. Many business activities are conducted without the assurance

${ }^{1}$ CliffordGeertz, 1992. Politik Kebudayaan (terjemahan) Yogyakarta: Penerbit Kanisius) h.3

${ }^{2}$ Harold R Issacs, Pemujaan Terhadap Kelompok Etnik (terjemahan). Jakarta: Yayasan Obor Indonesia. 1993, h. 54 
contracts, legal contracts or even a piece of paper. They do so on the basis of mutual trust, because they come from the same hometown, speak the same language or have the same surname, or of the same descendants. In short, the similarity of basic identity encourages mutual trust, at least at the first meeting they assume that they have the same behavior, because it comes from their ethic community. Ethnic consciousness that comes from the basic identity of an ethnic group is something that everyone must experience. This basic identity is the source of primordial bonding. Primordial bonds can be expressed in various forms of human life activity. The Policy of the Reform Era provides regional autonomy not necessarily solving this diversity problem. One thing that is unique in Indonesia, a government in such a district generally dominated by one tribe. The condition of local people like this can make people become more ethnocentrism. With such ethnocentrism can cause conflicts between tribes, races and religions. it is necessary to support multi-ethnic government in order to reduce conflicts.

Kuripan is one of the areas in Padang Ratu district in Central Lampung Regency, with population of 6,629 people spreadsout in 8 dusun (villages) consisting Lampungnese, Javanese, Sundanese and Balinese as the tribes in their community and the distribution of religion consists of Islam, Hinduism, Christianity and Buddhism.

Based on the problems as above, multi-cultural government needs to offer an alternative based on diversity utilization in society. The importance of conducting this research is based on the objective conditions of preliminary research data, when this problem is ignored in this time, it can become a problem in the future, and conflicts can be avoided due to the application of multiethnic based areas.

\section{B. Literature Review}

How important the concept of harmony culture as the basis of the movement to embrace the local diversity, so that ethnic, religious and group differences can build multiculturalism, as well as its contribution in building a strong tolerance. In a multiethnic society, ethnocentric patterns and social models can be counterproductive. Economic activities which is progressing rapidly and are controlled by an ethnic group are like assembling time bombs that will cause a social explosion at anytime. Socialization of multiethnic awareness can be implemented through the concept of social process, that is a way of relating between individuals or between groups or individuals with groups that cause a certain form of relationship. From these relationships, they are expected to be more familiar with each other andget closer, more sociable so thay can develop trust, and finally able to cooperate and work together. All of this can be understood as parts of human civilization.

The process of socialization starts from social interaction such as imitation behavior, suggestion, identification, and sympathy ${ }^{3}$. Social interaction will occur if it meets two conditions: social contact and communication. Every society interacts with each other, and fully adapts to the environment. This environment includes sociopolitical institutions of society and other organic elements. From

${ }^{3}$ M Pidarta, Landasan Pendidikan: Stimulus Ilmu Pendidikan BercorakIndonesia. Jakarta : Rineka Cipta.1997, h. 147 
the social interaction, it is expected that there will be no social strata between ethnic groups, and there should be the formation of civilization or interethnicacculturation. Civilization is a network of cultures. Commonly, every culture has its territory ${ }^{4}$. The civilization can be made through inter-ethnic interdependence. This interdependence can be a program (activities). Such activities can be: trade, art and education and that kind of activities will strenghten the power relationships.

Multiculturalism derives from a combination of three words namely, multi (many), culture, and isme (flow/understand). Multiculturalism is a paradigm of equality of all cultural expressions. It means that there is no stereotypical distinction between the "primitive" tribal culture and the civilization of modern industrial societies. Both have equality of values, and a deep role devotes to the specificity of their respective socio-historical roles ${ }^{5}$.

The multiculturalism in Islamic perspective can be found in many verses of the Qur'an. As we know, plurality in this world is inevitable realityl that has become sunnatullah (provision of Allah). In the Holy Qur'an Sura al-Hujarat verse 13

"O mankind, indeed We have created you from male and female and made you peoples and tribes that you may know one another. Indeed, the most noble of you in the sight of Allah is the most righteous of you. Indeed, Allah is Knowing and Acquainted6."

Moreover, Islamic treatises apply to all places. Islam also applies to all nations and classes therefore Islam is not reserved for Arabs only or Asian and others, but for all nations and classes whether it is black, white, red and brown-skinned people. In the Qur'an:

"And We have not sent you except comprehensively to mankind as a bringer of good tidings and a warner. But most of the people do not know." (QS. Saba': 28)7

According to verse 13 of al-Hujurat and Saba' verse 28 above, it is very clear that Islam basically considers the same to every human being, that is created and born from a pair of their parents (male and female). It leads every ethnic groups to know and understand the character of each group after each of them starts to create new group. Allah says in the Holy Qur'an:

"And of His signs is the creation of the heavens and the earth and the diversity of your languages and your colors. Indeed in that are signs for those of knowledge." (QS. ArRum: 22) 8

This verse explains that differences in color, language, and culture must be accepted as something positive and a sign of the greatness of Allah Almighty. Therefore, a Muslim needs to have positive attitude in response to pluralism and difference, that the existing plurality will strengthen and beautify the humanity.

${ }^{4}$ M Pidarta, Landasan Pendidikan: Stimulus Ilmu Pendidikan BercorakIndonesia. Jakarta : Rineka Cipta.1997, h. 147

${ }^{5}$ Parsudi Suparlan, Menuju Masyarakat Indonesia yang Multietnik, Simposium Internasional Bali, Jurnal Antropologi Indonesia, Denpasar Bali, 16-21 Juli 2002.

${ }^{6}$ Ibid., h. 172

${ }^{7}$ Departemen Agama RI, AL-Qur'an dan Terjemahnya, (Surabaya : CV Mahkota, 1996) h.986

${ }^{8}$ Ibid., h. 874 
With that kind of attitude, a Muslim will be able to act wisely and always motivated to do good deeds.

Semiotically, the verses of the Holy Qur'an that explains the need for unity and obedience in leadership shows that, in principle, Islam appreciates the difference of opinion and with the existence of a leader then the difference of opinion is directed to make better progress together, as explained in the Holy Qur'an:

"O you who have believed, obey Allah and obey the Messenger and those in authority among you. And if you disagree over anything, refer it to Allah and the Messenger, if you should believe in Allah and the Last Day. That is the best [way] and best in result." (QS. An-Nisa: 59) ${ }^{9}$

Then Messenger of Allah, Prophet Muhammad SAW said:

"One who defected from obedience (to the Amir) and separated from the main body of the Muslims - if he died in that state-would die the death of one belonging to the days of Jahiliyya (i.e. would not die as a Muslim) ${ }^{10}$."

The above verse and hadith explain the prohibitions of Allah to man so as not to separate from the congregation in order to create unity and brotherhood to respect each other and maintain the harmony of life.

The internal pluralism of muslims is also found in the practice of social grouping, party politics and educational model. The dynasties and caliphates that have existed in Islamic history such as the Mughal dynasty, Fathimiyah, Abasiah and the last Ottoman dynasty are concrete examples of the diversity presented in Islam. From this internal multiethnic perspective, the pluralism of religious cultural identity for Muslim societies is not merely a fact, more than that, multiethnic has become a passion, attitude and approach in living with others. The term culture of tolerance seems to have been largely unknown in the sociopolitical discourse of Indonesia, because during the authoritarian period of the New Order, tolerance became one of the values mobilized and reproduced repressively in the ideological package of Pancasila uniformity. In the militaristic realm, any movement of religious, regional, or ethnic exclusiveness tends to be regarded as SARA's (ethnicity, race, region, secterian) defiance, and is usually dealt with firmly by the state apparatus. Therefore, tolerance is understood as the ideology of the rulers rather than a part of the cultural process of the people.

\section{Research Method}

This research is considered as field research in which the researcher collects the data from field to be observed and concluded. The nature of this research is qualitative or naturalistic. The qualitative research is also intended so that the data can be obtained deeply in accordance with the meaning and facts founded in the field. According to Nasution, qualitative research is basically used to describe the problem comprehensively, holistically, integratively and deeply

\footnotetext{
${ }^{9}$ Ibid., h. 1076

${ }^{10}$ Al-Hafidz Ibnu Hajar Al-Asqalani, Bulughul MaramBabu Qitaali ahlil baghy, (Maktab Daar Ihya Al-Kitab Al-Arabiyah) h. 253
} 
through the activity of observing people and interacting with them in their environment ${ }^{11}$.

\section{C.1. Data Sources}

Sampling technique used in this research is snowball sampling in which initially the data obtained from the data sources is little then multiply during the data collecting process.This is done because the initial data can not provide satisfactory information, so thatadditional data is searched from other sources until the data can meet the needs of this research. By going through that process, complete data will be obtained. While the informants participated in this research was considered as reliable respondents, they were:

1. Head of Kesbangpolinmas Lampung (National Unity, Politics and Society Protection Agency of Lampung)

2. Heads of Sub-districts in Lampung

3. Heads of Villages in Lampung

4. Indigenous and religious leaders in Lampung

\section{C.2. Data Collecting Technique}

\section{Interview}

Interview is a means of collecting data used to obtain information directly from the sources ${ }^{12}$. Interviews is conducted to seek information clearly and in detailed from competent parties which is done systematically and based on research objectives ${ }^{13}$. The conversation is conducted by two parties, the interviewer who asks questions and interviewee who is being interviewed and answers the question from the interviewer.

\section{Observation}

In this techniques, the researcher plays role as the observeras well as research participant. Observation is a technique which facilitates the researcher to experience the real situation supported by systematic data collection and recording of the research subject ${ }^{14}$. Spradley divides this technique into several stages, including descriptive observation that describes the situation and activities occurred in the field. An after that an analysis of the recorded data is conducted, and the data will be narrowed down in selection stage.

\section{Documentation}

Documentation is used to record or quote the data from documents or principles which is considered important to complete the data which has been obtained directly from the respondent previously. From this technique, qualitative data on portrait of harmony based on multiethnic village in Central Lampung can be obtained.

\footnotetext{
${ }^{11}$ Nasution. S, Metode Penelitian Naturalistik Kualitatif, (Bandung: Tarsito, 1991), h. 5

12 Riduan, Belajar Mudah Penelitian Untuk Guru Karyawan dan Peneliti Pemula (Bandung : Alfabeta, 2004) h.74

${ }^{13}$ Nana Sudjana Ibrahim, Pengantar dan Penelitian Pendidikan (Bandung: Sinar Baru,1989), h. 64

${ }^{14}$ Nasution. S, Metode Penelitian..., h. 10
} 


\section{C.3. Data Analysis Technique}

The data analysis on qualitative research is carried out from the beginning to the end process when the research is being conducted with the expectation of consistency in data analysis. Descriptive analysis specifically Interactive Analysis Model from Miles and Huberman is used to analyze the data collected in this research. Miles and Huberman stated: we define analysis as consisting of three concurrent flow of activity, data reduction, display data and conclusion drawing/verification ${ }^{15}$. These three phases occur continuously during the implementation of the study, both in the data collection period and after the data collected entirely. The description of each component is as follows:

1. Data reduction, defined as a research process, focuses on simplification and transformation of coarse data arising from written records in the field. Reduction is done since data collection begun by making a summary, encoding, browsing themes, creating clusters, writing memos with the intention of excluding irrelevant data / information. Data reduction is a form of analysis to sharpen, classify, direct, discard unnecessary data to produce a potential data summary for answering research questions ${ }^{16}$.

2. Data display is to describe a set of arranged information that provides the possibility of drawing conclusions and taking action. The presentation of qualitative data is presented in the form of narrative text. The presentation can also be in the form of matrices, table diagrams, and charts. Everything is designed to combine information composed in a coherent and easily understood form ${ }^{17}$.

3. Conclucion drawing/verification is the last process of the data analysis. Drawing conclusions is in the form of interpretation activities which finds the meaning of data that has been presented. The ways used in this stage varies. It can be contrast comparison, find patterns and themes, clustering (grouping), and connecting with each other. Meanings that researchers have to be tested in terms of their validity, compatibility and consistency ${ }^{18}$.

\section{Conclusion}

Increasing population will make life difficult for middle-class society because the demand for employment is higher, while the number of available jobs is not increasing (constant). The high number of labor supply will affect the low cost of labor received, so that the life in the future will even be more difficult. "While the life of the capitalist (bourgeois) group will be more abundant with its luxuries. These symptoms lead to social inequality that can possibly cause social conflicts." "Conflict between social classes is usually a vertical conflict, in which happened between upper social class and lower social class. This conflict occurs because of the different interests between the two existing classes or social classes. "Conflict between social classes is usually more emphasized on the conflict between laborers and employers within the structure of industrial society and the conflict between patrons and clients in feudal society structures. A group

${ }^{15}$ Miles, Huberman, Michael Bray, America,Qualitative Data Analysis a Sourcebook Ofnew Methods (London: Sage Publication ltd., 1995), h 10

${ }^{16}$ Sugiono, Metode Penelitian..., h.338-340.

${ }^{17}$ Sugiono, Metode Penelitian...,h. 341.

${ }^{18}$ Sugiono, Metode Penelitian..., h. 345. 
of workers demanding wage improvements to governments and corporations is a manifestation of one of the conflicts between groups. Termination of employment $(\mathrm{PHK})$ is a form of social conflict between social classes that exist. The main factor that triggers the conflict usually lies in the difference of opinion in which the employer who owns the business capital has higher income, while the workers who have the vigor earn lower income, so this situation raises the issue of injustice, social inequality, and so on. The tension of production relation in the capitalist production system between the bourgeoisie and the proletarian class led to a form of massive social movement, a revolution. The tension of production relation occurs when the proletarian class has realized the exploitation of the bourgeoisie against them. People who are very convinced of radical social change and longing for it, regardless their moral and academic background, are the reality of class power against another weak class. This class conflict occurs because of exploitation and social change which is the dialectical process that is strongly related to the conflict And economic determinism. The conflict between the bourgeoisie and the proletarian is deep and difficult to resolve because it has difference in class consciousness not in the way of life. The difference between the bourgeoisie and the proletarian class is not only in their way of life, but also in the way of thinking. Despite the conflict that occurs in the life of a society that distinguishes private interests and discriminates the bourgeoisie and the proletariat, it can create a relationship that unifies societal states. However those situation can cause an impact or consequences in their lives. The multiethnic in practice is a strategy of social integration in which cultural diversity is truly acknowledged and respected, so that it can be effectively functioned in addressing every issue of separatism and social disintegration. Experience teaches, not the spirit of unity or oneness (tunggal ika) that is the most potential which canlead to strong unity, but rather the recognition towards plurality (kebhinnekaan) of this nation's culture that more guarantee the unity of the nation towards a democratic social reform.

\section{Bibliography}

A.Y Cohen,Schools and Civilizational States, dalam The Social Sciences and The Comparative Study of Education systems. (Joseph Fischer; editor).Pennsylvania: International Textbook Company.

Abdullah Aly.. "Menggagas Pendidikan Islam Multietnik di Indonesia", dalam Jurnal Ishraqi, Volume II Nomor 1, Januari-Juli 2003

Abin Syamsuddin Makmun, Psikologi Pendidikan,. Bandung: Rosda Karya Remaja, 2003

Ahmad D. Marimba, Pengantar Filsafat Islam, Bandung: Al-Ma'rif, 1980

Al-Tibawi, Islamic Education, Lirzac and Company, Ltd. London : 1972

Arifin, Filsafat Pendidikan Islam, Jakarta : Bumi Aksara, 1994

Bank, James A. dan Cherry A. McGee ed. Handbook of Research on Multicultural Education San Francisco: Jossey-Bass, 2001

Bennett,C. \& Spalding,E. "Teaching the Social Studies: Multiple Approaches for Multiple Perspectives". In Theory and Reseach in Social Education. XX:3

Burhan Bungin ed, Metodologi Penelitian Kualitatif, Aktualisasi Metodologis Ke Arah Ragam Varian Kontemporer, Jakarta : PT RajaGrafindo Persada, September, 2001 
Charles Taylor. "The Politics of Recognation" dalam Amy Gutman. Multiculturalism, Examining the Politics of Recognation Princenton: Princenton University Press, 1994

Clifford Geertz, 1992. Politik Kebudayaan (terjemahan) Yogyakarta : Penerbit Kanisius)

Dawam, Ainurrofiq, Pendidikan Multietnik, Yogyakarta: Inspeal, 2006

Dedi Supriawan dan A. Benyamin Surasega, 1990. Strategi Belajar Mengajar Diktat KuliaBandung: FPTK-IKIP Bandung, 1990

Departemen Agama RI, Al-Qur'an dan Terjemahnya, Surabaya : CV Mahkota, 1996

Depdiknas, Konsep pendidikan Kecakapan HIdup Life Skill Education,Tim Broad Based Education, 2002

Faisal, Sanapiah, Penelitian Kualitatif: Dasar-Dasar dan Aplikasinya. Malang : YA3, 1990

Felix Sitorus, Penelitian Kualitatif suatu perkenalan, Bogor : Kelompok Dokumentasi Ilmu Sosial, Fakultas Pertanian, IPB, 1998

Fuad Hasaan dan Koentjaraningrat, "Beberapa Azas Penelitian Ilmiah", dalam: Koentjaraningarat, Metode-Metode Pene1itian Masyarakat, Cetakan IV, Jakarta: Gramedia, 1981

Hadari Nawawi, Metode Penelitian Bidang Sosial, Yogyakarta : Gadjah Mada, University Press, 1988

Hafidz Hasan, Husen Al-Qabbani dan Najib Yusuf Al-Badawi, Ushulut Tarbiyah Wa'alimun Nafsi, Mesir : Daarul Jihad, 1996

Harold R Issacs, Pemujaan Terhadap Kelompok Etnik (terjemahan). Jakarta : Yayasan Obor Indonesia.1993

Ibnu Hajar Al-Asqalani, Bulughul Maram Babu Qitaali ahlil baghy, Maktab Daar Ihya Al-Kitab Al-Arabiyah

Ibrahim Ash Shomad Muthar dan Abdul Gani Abud, At Tarbiyah Mu'ashiroh, Mesir : Daarul Fikr, 1977

Ida Bagus Mantra, Filsafat Penelitian dan Metode Penelitian Sosial, Edisi II, Cetakan I, Yogyakarta: Pustaka Pelajar, 2008

Idi, Abdullah, Pengembangan Kurikulum: Teori dan Praktik, Jakarta : Gaya Media Pratama, 1999

IKA UIN Syarif Hidayatullah, Majalah: Tsaqafah: Mengagas Pendidikan Multietnik, Vol. I No:2, 2003

Kaelan, Metode Penelitian Kualitafif Bidang Filsafat, Yogyakarta: Paradigma, 2005

Kartini Kartono, Pengantar Metodologi Riset Sosial, Bandung : Penerbit Mandar Maju, Cetakan ke VIII, 1996

Lexy J. Moleong, Metodologi Penelitian Kualitatif, Bandung : Remadja Karya, Cetakan Pertama, 1989

Liliweri, Alo, Prasangka \& Konflik: Komunikasi Lintas Budaya Masyarakat Multietnik . Yogyakarta : LkiS, 2005

Lois Gootschalk, Understanding History, A. Primer of Historical Method, Terjemah Nogroho Noto Susanto, Jakarta : UI Press, 1985

M Pidarta, Landasan Pendidikan: Stimulus Ilmu Pendidikan Bercorak Indonesia. Jakarta : Rineka Cipta.1997 
Muhaimin, Suti'ah, Nur Ali, Paradigma Pendidikan Islam: Upaya mengefektifkan pendidikan agama Islam di sekolah, Bandung : PT Remaja Rosdakarya, 2002

Nasrudin Razaq,, Dinul Islam, Al-Ma'arif, Bandung, 1986

Parsudi Suparlan, Menuju Masyarakat Indonesia yang Multietnik, Simposium Internasional Bali, Jurnal Antropologi Indonesia, Denpasar Bali, 16-21 Juli 2002.

Parsudi Suparlan, Menuju Masyarakat Indonesia yang Multietnik, Simposium Internasional Bali, Jurnal Antropologi Indonesia, Denpasar Bali, 16-21 Juli 2002

Rohmat Mulyana, Mengartikulasikan Pendidikan Nilai, Bandung : Alfabeta, 2004

Said Aqil Husin, Al-Munawwar, Aktualisasi Nilai-Nilai Qur'ani dalam Sistem Pendidikan Islam, Jakarta: Ciputat Press, 2003

Sayyid Sabiq, Al-Aqoidul Islamiyah, Mesir : Daarul Kitabil Hadits, 1967

Scott Lash dan Mike Featherstone ed., Recognition And Difference: Politics, Identity, Multiculture London: Sage Publication, 2002

Skeel, D.J. Elementary Social Studies: Challenge for Tomarrow"s World. New York: Harcourt Brace College Publishers, 1995

Sleeter, C.E. \& Grant, Making Choices for Multicultural Education, Fife Approaches to Race, Class, and Gender. New York: Macmillan Publishing Company, 1988

Sonia Nieto. Language, Culture and Teaching Mahwah, NJ: Lawrence Earlbaum, 2002

Syaiful Sagala, Konsep dan Makna Pembelajaran, Bandung : Alfabeta, 2005

Tilaar, A. R, Perubahan Sosial dan Pendidikan: Pengantar Pedagogik Transformatif untuk Indonesia, Jakarta : Grasindo, 2002

Tim Perumusan UU RI, Undang-Undang Sistem Pendidikan Nasional Nomor 20 tahun 2003, Jakarta : CV Eko Jaya, 2003

Wina Senjaya, Strategi Pembelajaran; Berorientasi Standar Proses Pendidikan. Jakarta: Kencana Prenada Media Group, 2008

Yudi Latif, Intelegensia Muslim dan Kuasa: genealogi Inteligensia Muslim Indonesia abad ke-20. Bandung, Mizan, 2005 